\title{
Marek Wróblewski
}

Uniwersytet Wrocławski

marek.wroblewski@uni.wroc.pl

Katarzyna Stecz

katarzyna.stecz@trade.gov.pl

WYNIKI XI KONFERENCJI MINISTERIALNEJ WTO AKTUALNE PROBLEMY, TENDENCJE I WYZWANIA DLA MULTILATERALNEGO SYSTEMU HANDLU

THE RESULTS OF THE $11^{\text {TH }}$ WTO MINISTERIAL CONFERENCE - CURRENT PROBLEMS, TRENDS AND CHALLENGES FOR THE MULTILATERAL TRADING SYSTEM

DOI: $10.15611 / \mathrm{pn} .2018 .523 .34$

JEL Classification: F13, F51, F60

Streszczenie: Multilateralny system handlu przeżywa poważny i długotrwały kryzys, którego przejawy szczególnie wyraźnie widać przez pryzmat problemów identyfikowanych w pracach przebiegających na forum WTO. Z tego względu niniejszy artykuł podejmuje próbę oceny i interpretacji wyników ostatniej XI Konferencji Ministerialnej (XI KM) WTO i w tym kontekście także identyfikacji aktualnych problemów, trendów i wyzwań obserwowanych w multilateralnym systemie handlu. W wymiarze metodologicznym opracowanie oparto przede wszystkim na krytycznej analizie dokumentów źródłowych WTO, a także obserwacji uczestniczącej i wywiadach bezpośrednich z uczestnikami XI KM. Uzyskane wyniki badań sugerują, iż kryzys WTO ulega pogłębieniu, zwłaszcza w filarze negocjacyjnym. W związku z tym podejście plurilateralne w pracach WTO może stanowić obecnie jedyny realnie dostępny model umożliwiający kontynuację rozmów, zwłaszcza w odniesieniu do tzw. nowych inicjatyw handlowych, ze względu na brak możliwości osiągnięcia porozumienia multilateralnego w większości aktualnych obszarów negocjacji.

Słowa kluczowe: WTO, XI Konferencja Ministerialna, kryzys WTO, multilateralny system handlu, inicjatywy plurilateralne.

Summary: The multilateral trading system is experiencing a serious and long-lasting crisis, the manifestation of which is clearly visible through the prism of the current problems identified in the work carried out in the WTO forum. Therefore, this article attempts to evaluate and interpret the results of the last XI Ministerial Conference (XI MC) of the WTO and in this context attempts to identify current problems, trends, and challenges observed in the multilateral trading system. In the methodological dimension, the study was based primarily 
on the critical analysis of WTO source documents, as well as a participant observation and direct interviews with XI MC attendees. The obtained research results suggest that the WTO crisis is deepening, especially in the negotiating pillar. As a consequence, the plurilateral approach in the WTO work may currently be the only feasible way to continue the talks, especially with regard to the so-called new trade initiatives, due to the inability to reach a multilateral agreement in most current areas of negotiations.

Keywords: WTO, XI Ministerial Conference, WTO crisis, multilateral trade system, plurilateral initiatives.

\section{Wstęp}

Aktualna sytuacja w relacjach międzynarodowych, mająca również wpływ na multilateralny reżim handlowy, wydaje się mieć charakter dychotomiczny. Z jednej strony zmiany i skutki tych zmian obserwowane we współczesnej gospodarce światowej związane z postępującym procesem globalizacji oraz poważne wyzwania cywilizacyjne implikują rosnące zainteresowanie, a przez to także popyt na różne formy koordynacji działań w skali ponadnarodowej. Tym bardziej, że identyfikowane są poważne problemy wykraczające w swojej skali poza granice poszczególnych państw czy nawet regionów świata. $Z$ drugiej jednak strony kluczowi państwowi aktorzy relacji międzynarodowych, pomimo innych deklaracji werbalnych, wykazują daleko idącą niechęć do delegowania swoich uprawnień na poziom supranarodowy i - szerzej - niechęć do integracji działań w wymiarze globalnym. Utrzymuje się przy tym także (a niekiedy nawet nasila) tradycyjna percepcja suwerenności kraju wraz z towarzyszącymi jej atrybutami, która następnie wywiera znaczny wpływ na funkcjonowanie i efektywność organizacji międzynarodowych. W sferze handlu międzynarodowego tworzy to obecnie sprzyjające warunki dla swoistej restauracji idei protekcjonistycznych, choć często w zmodernizowanej formie, które eksponują konieczność wykorzystania różnych instrumentów (zwłaszcza pozataryfowych) dla realizacji partykularnych interesów przez określone państwa (lub grupy państw). Baldvin i Evenett zauważają, iż tendencje protekcjonistyczne odżyły zwłaszcza w okresie ostatniego globalnego kryzysu finansowego, ale miały bardziej subtelny charakter [Baldwin, Evenett 2009]. W ostatnim raporcie Światowej Organizacji Handlu (WTO) dotyczącym przeglądu polityki handlowej wskazano, iż w okresie październik 2016-maj 2017 kraje członkowskie WTO implementowały 74 nowe instrumenty ograniczające wymianę handlową [WTO 2017]. Natomiast według danych Komisji Europejskiej (KE) tylko w 2016 roku implementowano na świecie 36 nowych barier w obszarze handlu i inwestycji, które spowodowały potencjalne straty dla firm Wspólnoty na poziomie 27,17 mld euro. Jednocześnie w tym okresie KE wskazuje na zidentyfikowanie łącznie 327 aktywnych tego rodzaju barier utrzymywanych przez różne kraje [European Commission 2016]. Uwzględniając zatem wskazane negatywne trendy zewnętrzne obserwowane w gospodarce globalnej oraz 
trudną sytuację wewnętrzną w WTO, można zauważyć, iż w tych warunkach przedmiotowa instytucja doświadcza poważnych turbulencji i jej efektywność operacyjna ulega znacznemu ograniczeniu. W rezultacie WTO, uznawana za instytucjonalną emanację multilateralnego systemu handlu, znajduje się w poważnym i długotrwałym kryzysie.

Ze względu zatem na zarysowane powyżej okoliczności celem tego artykułu jest próba oceny wyników ostatniej XI Konferencji Ministerialnej WTO w Buenos Aires z 2017 roku i w tym kontekście próba identyfikacji aktualnych problemów, trendów i wyzwań obserwowanych w multilateralnym systemie handlu. W wymiarze metodologicznym niniejsze opracowanie zostało oparte przede wszystkim na krytycznej analizie dokumentów źródłowych WTO oraz relewantnych pozycji literatury przedmiotu, a także obserwacji uczestniczącej i wywiadach bezpośrednich przeprowadzonych z uczestnikami wskazanej konferencji oraz uczestnikami prac prowadzonych na forum WTO w Genewie'. W związku z tym istotna część niniejszego opracowania została oparta na zebranym materiale empirycznym.

\section{Wyniki XI Konferencji Ministerialnej}

XI Konferencja Ministerialna (XI KM) WTO odbyła się Buenos Aires w dniach 10-13 grudnia 2017 roku. Należy zauważyć w tym miejscu, iż konferencja ministerialna - zgodnie z art. IV Porozumienia ustanawiającego WTO [WTO 1995] - pełni formalnie funkcję najwyższej władzy przedmiotowej organizacji. Stąd też regularnie organizowane konferencje ministerialne (zwykle co dwa lata) są potencjalnie niezwykle ważne dla funkcjonowania przedmiotowej instytucji ze względu przede wszystkim na specyfikę procesu decyzyjnego WTO. Jednocześnie konferencje ministerialne stanowią ważne forum dla oceny działalności wskazanej instytucji oraz wyznaczania dalszych kierunków jej prac.

Generalnie rzecz ujmując, należy stwierdzić, że 11 Konferencja Ministerialna nie przyniosła spodziewanych rezultatów negocjacyjnych i jej wynik można określić jako nadzwyczaj skromny. Nawet w tych obszarach negocjacyjnych, które wydawały się jeszcze przed konferencją - podczas prac na forum WTO w Genewie - najbardziej perspektywiczne pod względem możliwości uzyskania konkretnych wyników negocjacyjnych (m.in. zapasy publiczne dla utrzymania bezpieczeństwa żywnościowego, subsydia w rybołówstwie, wsparcie krajowe w usługach), nie osiągnięto znaczącego wyniku. W efekcie prowadzone podczas konferencji prace pozwoliły tylko na przygotowanie kilku relatywnie ogólnych decyzji ministerialnych (wskazanych poniżej), zaliczanych do multilateralnego dorobku WTO.

1 Autorzy niniejszego opracowania byli uczestnikami 11 Konferencji Ministerialnej WTO w Buenos Aires w dniach 10-13 grudnia 2017 roku, a także partycypowali w pracach prowadzonych na forum WTO w Genewie przed wskazaną konferencją oraz po jej zakończeniu. 


\section{Ministerial Decision on Fisheries Subsidies WT/MIN(17)/64 [WTO 2017a]}

Decyzja w sprawie subsydiów w rybołówstwie - kraje członkowskie WTO wyraziły zgodę na kontynuację negocjacji w zakresie zakazu stosowania subsydiów w rybołówstwie z wolą przyjęcia stosownego porozumienia multilateralnego na Konferencji Ministerialnej w 2019 roku. Porozumienie takie miałoby w przyszłości zakazywać określonych form subsydiowania w rybołówstwie, które przyczyniają się do rozwoju nadmiernych mocy połowowych oraz przełowienia zasobów, a także eliminować stosowanie subsydiów przyczyniających się do nielegalnych, niezgłoszonych i niezgodnych z przepisami połowów (tzw. IUU-fishing, illegal, unreported, and unregulated). Jednocześnie przyszłe porozumienie w tym sektorze powinno uwzględniać specjalne traktowanie krajów rozwijających się. Przedmiotowa decyzja obejmuje również zobowiązanie krajów członkowskich (zgodnie z art. 25.3 Porozumienia w sprawie subsydiów i środków wyrównawczych [WTO 1995a]) do dalszego wzmocnienia transparentności w procesie notyfikacji stosowanych subsydiów w rybołówstwie.

\section{Work Programme on Electronic Commerce WT/MIN(17)/65 [WTO 2017b]}

Decyzja w sprawie programu prac w obszarze handlu elektronicznego - kraje członkowskie WTO zgodziły się na kontynuowanie prac z wykorzystaniem Programu prac dotyczącego handlu elektronicznego, który został przyjęty jeszcze w 1998 roku. Zaaprobowano także przedłużenie moratorium na nakładanie obciążeń celnych na transmisje elektroniczne do 2019 roku. Wyrażono także wolę zintensyfikowania prac w sferze handlu elektronicznego oraz przygotowanie przeglądu wyników w tym zakresie przez Radę Generalną WTO w 2018 i 2019 roku.

\section{TRIPS non-violation and situation complaints WT/MIN(17)/66 [WTO 2017c]}

Decyzja w sprawie TRIPS non-violation and situation complaints - kraje członkowskie WTO zgodziły się na przedłużenie moratorium na wnoszenie skarg w obszarze TRIPS w odniesieniu do sytuacji, gdy co prawda nie nastąpiło złamanie postanowień porozumienia, ale dany kraj udowodni potencjalnie utracone korzyści z tytułu działań innego kraju (Porozumienie w sprawie Handlowych Aspektów Praw Własności Intelektualnej [WTO 1995b]).

\section{Work Programme on Small Economies WT/MIN(17)/63 [WTO 2017d]}

Decyzja w sprawie Programu prac w obszarze małych gospodarek - kraje członkowskie WTO wyraziły gotowość do kontynuacji prac odnoszących się do wsparcia małych gospodarek. Przede wszystkim prace te mają się koncentrować na wypracowaniu ułatwień w handlu dla tego rodzaju systemów ekonomicznych.

W trakcie 11 KM zainteresowane kraje (w różnych konfiguracjach) podpisały dodatkowo cztery wspólne deklaracje wyrażające wolę kontynuacji rozmów/prac w obszarach regulacji krajowych w usługach [WTO 2017e], handlu elektronicznego [WTO 2017f], ułatwień dla inwestycji [WTO 2017g] oraz programu wsparcia dla 
mikro-, małych i średnich przedsiębiorstw (MMSP) [WTO 2017h]. Należy jednak zauważyć, iż wymienione deklaracje - podobnie jak przywołane wcześniej decyzje ministerialne - mają również charakter bardzo ogólnego zaprezentowania pozytywnego nastawienia poszczególnych sygnatariuszy do określonego tematu prac, natomiast nie stanowią żadnego zobowiązania w sensie formalnym. Można je traktować tylko jako pewien rodzaj politycznej (ale niewiążącej) manifestacji zainteresowania danym obszarem rozmów. Tym samym na tym etapie nie stanowią one formalnie części dorobku WTO.

W związku z powyższym można stwierdzić, iż XI KM WTO nie przyniosła przełomu w poszczególnych obszarach negocjacyjnych, które stanowiły oś merytoryczną prowadzonych rozmów w czasie jej trwania. Nie udało się również osiągnąć porozumienia multilateralnego $\mathrm{w}$ żadnej sferze negocjacji, a wyraźny impas w rozmowach, który był już obserwowany wcześniej w Genewie, nie został przełamany. Należy zatem wyeksponować fakt, iż zaprezentowane powyżej syntetycznie decyzje ministerialne podjęte na XI KM WTO oraz wspólne oświadczenia nie stanowią w zasadzie żadnego realnego postępu negocjacyjnego. Pomimo więc licznych deklaracji krajów członkowskich, werbalnie wspierających multilateralny system handlu i relewantność WTO (składanych podczas sesji plenarnych KM w Buenos Aires), nie było możliwe osiągnięcie zbliżenia stanowisk i wypracowania konsensusu. Jedynie w przypadku subsydiów w rybołówstwie i IUU wydaje się, iż w zasadzie panuje zgoda wśród krajów członkowskich WTO odnośnie do konieczności kontynuacji prac $\mathrm{w}$ formacie multilateralnym $\mathrm{i}$ istnieje realna chęć osiągnięcia porozumienia w tym zakresie do 2019 roku (chociaż także tutaj nie można mieć pewności, co potwierdzają doświadczenia z okresu prac w Genewie przed XI KM w 2017 roku). Wynika to jednak głównie z faktu, iż decyzja dotycząca uregulowania tej kwestii jest częścią Rundy Doha, zatem nawet kraje rozwijające się z tego powodu nie podważają zasadności przedmiotowych negocjacji w tym obszarze.

W tym kontekście warto jeszcze zwrócić uwagę na końcowe przemówienie dyrektora generalnego (DG) WTO Roberto Azevedo wygłoszone podczas XI KM. Dyrektor generalny wyraził bowiem generalnie głębokie rozczarowanie wynikami konferencji, w tym zwłaszcza brakiem kompromisu w wielu ważnych obszarach rozmów. Jak zauważył, nie było jednomyślności nawet w kwestiach tak elementarnych, jak ustalenie programu przyszłych prac w części obszarów rozmów. W przemówieniu końcowym DG za znamienne można uznać wyeksponowanie istoty multilateralnego systemu handlu. Według DG ,,multilateralizm nie oznacza, że wszyscy uczestnicy negocjacji uzyskają pożądane przez siebie wyniki, ale to, co jest w danym czasie możliwe. Nie należy też oczekiwać efektywności od systemu multilateralnego handlu i jednocześnie korzystnych tylko dla siebie (danego kraju) wyników" [WTO 2017i]. Ta konstatacja, zdaniem DG Azevedo, powinna stanowić rodzaj wskazówki na przyszłość w odniesieniu do prac na forum WTO. W istocie rzeczy zdolność bowiem do osiągania kompromisu jest niezbędna dla zachowania sprawności multilateralnego systemu handlu i WTO, nawet jeśli niekiedy ten kompromis 
jest trudny do akceptacji dla poszczególnych krajów członkowskich organizacji. W rezultacie XI KM, na co wskazuje faktyczny brak realnych wyników rozmów, zakończyła się więc kontynuacją zapaści w filarze negocjacyjnym. Należy dodać, iż jest to uznawane powszechnie, także wewnątrz samej WTO, za wyraźny symptom dalszego pogłębiania się kryzysu tej instytucji.

\section{Kryzys WTO i wyzwania dla multilateralnego systemu handlu}

Wspomniany wcześniej ponowny rozwój nacjonalizmu ekonomicznego jako jedna z obserwowanych obecnie tendencji w gospodarce światowej, przy jednoczesnej złożoności współczesnej wymiany handlowej, a także fiasko XI KM, znacznie utrudniają osiągnięcie wymiernych rezultatów negocjacyjnych w multilateralnym systemie handlu i negatywnie wpływają na efektywność operacyjną WTO. W rezultacie powstała sytuacja staje się zarzewiem głębokiego kryzysu WTO, który jest szczególnie widoczny i odczuwalny właśnie w filarze negocjacyjnym tej instytucji. Identyfikuje się więc obecnie kryzys egzystencjonalny (lub organiczny), osłabiający wyraźnie legitymizację tej organizacji w architekturze gospodarki światowej. Elsig wskazuje również na kryzys adaptabilności WTO wynikający z braku dostosowania przedmiotowej instytucji do poważnych zmian, jakie zaszły w gospodarce światowej (a więc w otoczeniu WTO) od momentu jej powstania [Elsig 2016]. Kryzys ten jednak nie jest z pewnością nowym fenomenem, który ujawnił się dopiero w ostatnich latach. Niemal od powstania WTO wskazywano wielokrotnie na różnego rodzaju dysfunkcjonalności tej instytucji, a w 2005 roku (zaledwie 10 lat od utworzenia organizacji) ówczesny dyrektor generalny WTO - Pascal Lamy - stwierdzał explicite po VI KM w Hongkongu, iż „instytucja znajduje się w głębokim kryzysie” [WTO 2006]. Baldwin trafnie zauważa, iż pomimo poważnych perturbacji w ramach Rundy Doha i braku wyników negocjacyjnych od 2001 roku do 2016 udawało się wprawdzie częściowo redukować np. wysokość stosowanych stawek celnych w różnych regionach świata, ale osiągano takie rezultaty tylko poza systemem WTO (w rozmowach bilateralnych lub też w ramach porozumień regionalnych), co wskazuje na wyraźne problemy tej instytucji [Baldwin 2016; Van Grasstek 2013]. W tym świetle brak porozumienia w kluczowych obszarach rozmów podczas XI KM w Buenos Aires w 2017 roku nie może być zaskoczeniem i należy to uznać za pochodną szerszych i długotrwałych negatywnych tendencji obserwowanych od co najmniej kilkunastu lat wewnątrz WTO.

Przebieg zarówno prac w Genewie przed konferencją, podczas XI KM, jak i w pierwszym kwartale 2018 roku wskazuje, iż trudno obecnie dostrzec możliwości szybkiego przełamania impasu w prowadzonych negocjacjach oraz zwiększenia efektywności WTO (co byłoby oznaką przezwyciężenia owego kryzysu). Tym bardziej że postawa państw mających w praktyce duże znaczenie dla kierunków prac WTO nie napawa optymizmem (m.in. postawa Stanów Zjednoczonych, Chin i Indii). Rezultatem tego jest systematyczne zmniejszanie ambicji negocjacyjnych 
w ostatnich latach w prowadzonych rozmowach na forum przedmiotowej organizacji, ale nawet takie podejście nie spowodowało jak dotąd wyraźnej poprawy sytuacji. W rezultacie można skonstatować, iż WTO ma coraz mniejszą zdolność operacyjną do działania w filarze negocjacyjnym, co przy równolegle obecnym de facto paraliżu organu odwoławczego (tzw. Appellate Body) w systemie rozstrzygania sporów WTO znacznie zmniejsza możliwości realnego działania tej instytucji i osłabia jej pozycję w gospodarce światowej.

Należy zauważyć, iż zasadniczym źródłem problemów dla działalności operacyjnej WTO jest poważna zmiana geometrii potencjałów ekonomicznych w gospodarce światowej, a system reprezentowany przez GATT/WTO jest w istocie rzeczy wytworem projektowanego porządku globalnego w wymiarze gospodarczym po II wojnie światowej. Od tego czasu wyraźnie wzrosła jednak rola i znaczenie zwłaszcza dużych gospodarek wschodzących (m.in. Chin, Indii, Brazylii) w globalnych przepływach towarów, usług i kapitału. W rezultacie tradycyjny model handlu światowego zdominowany przez triadę Stany Zjednoczone-UE-Japonia nie odzwierciedla już w pełni realnego układu sił w gospodarce światowej, a punkt ciężkości aktywności ekonomicznej przesuwa się stopniowo w kierunku krajów rozwijających się. Ponadto warto dodać, iż nawet w wymiarze czysto ilościowym, co nie jest bez znaczenia, liczba krajów rozwijających się w WTO jest istotnie większa aniżeli krajów rozwiniętych ${ }^{2}$. W związku z tym państwa wysoko rozwinięte nie są już w stanie w łatwy sposób narzucić swojej wizji kształtowania porządku handlowego w określonych obszarach problemowych czy też włączania do agendy rozmów preferowanych tematów. Nowicki słusznie wskazuje, iż kraje rozwijające się, tworząc również koalicje na forum WTO, przeciwstawiają często swój punkt widzenia krajom rozwiniętym [Nowicki 2014]. Jak trafnie zauważał Petersman, przywództwo potęg handlowych (jak USA czy UE), chociaż niezbędne, to jednak nie jest już wystarczające dla nadania odpowiedniej dynamiki rozmowom na forum WTO [Petersman (red.) 2005].

Jednocześnie należy wyeksponować fakt, iż istnieją obiektywnie poważne różnice w podejściu do wielu konkretnych kwestii handlowych pomiędzy tymi dwiema grupami krajów, które zasadniczo wynikają z innej trajektorii rozwoju i rozmaitych odmiennych uwarunkowań strukturalnych oraz historycznych państw rozwiniętych i rozwijających się. W efekcie z naturalnych względów odmienne są też interesy ekonomiczne wskazanych grup. Właśnie w następstwie tych różnic utrzymują się głębokie podziały w odniesieniu do percepcji funkcjonowania WTO oraz podejmowanych tematów negocjacyjnych. Generalnie zasadnicza polaryzacja stanowisk sprowadza się aktualnie do tego, iż kraje rozwijające się dążą stale do wzmocnienia znaczenia problematyki rozwojowej $\mathrm{w}$ agendzie prac WTO oraz często zabiegają

${ }^{2}$ Co więcej, znacząco większa część populacji światowej żyje w krajach rozwijających się. W związku z tym niejako w naturalny sposób handel międzynarodowy powinien generować określone korzyści dla mieszkańców tych krajów, co jednak w percepcji tych państw/społeczeństw odbywa się w niesatysfakcjonującym stopniu. 
o specjalne (preferencyjne) ich traktowanie, podczas gdy kraje rozwinięte zainteresowane są włączeniem tzw. nowych tematów do procesu negocjacji na forum organizacji (m.in. handlu elektronicznego, ułatwień dla inwestycji, wsparcia MMSP) oraz respektowaniem istniejących już regulacji, w tym zwłaszcza akcentują potrzebę transparencji i wzmocnienia procedur notyfikacji. Warto w tym miejscu dodać, iż Stany Zjednoczone szczególnie intensywnie zabiegają obecnie o wzmocnienie tych funkcji w ramach prac regularnych organów i komitetów WTO. Kwestie transparencji i notyfikacji w ich percepcji nie były bowiem satysfakcjonująco implementowane ze względu na koncentrację krajów członkowskich na filarze negocjacyjnym WTO. Poza tym szczególnie istotny pozostaje nadal podział między krajami członkowskim WTO w odniesieniu do postrzegania dalszych losów Rundy Doha (Doha Development Agenda, DDA). Kraje rozwijające się utrzymują, że runda ta powinna być zakończona konkretnymi wynikami negocjacyjnymi, podczas gdy kraje rozwinięte uważają, że powinna być ona zakończona bez przesądzeń (a uwaga WTO winna się skupić raczej na przyszłości i adekwatności działań tej instytucji wobec intensywnie zmieniających się realiów oraz nowego układu potencjałów w handlu światowym). W rezultacie, uwzględniając specyfikę procesu decyzyjnego funkcjonującego w ramach WTO, trudno o osiągnięcie akceptowalnego dla wszystkich uczestników rozmów kompromisu. Ponadto część badaczy zwraca uwagę, iż korzyści z członkostwa w WTO są odczuwane w różny sposób przez kraje członkowskie (np. małe gospodarki, niemające odpowiedniej siły przetargowej dla samodzielnego kształtowania korzystnych dla siebie warunków handlu w relacjach bilateralnych, w większym stopniu doceniają partycypację w WTO) [Drabek 2010]. Stąd też percepcja WTO oraz oczekiwania wobec tej instytucji często są skrajnie rozbieżne wśród obecnie 164 krajów członkowskich.

Kryzys WTO, jak wcześniej sygnalizowano, ma również związek z innymi poważnymi zmianami jakościowymi, które zaszły w ostatnich dwóch dekadach w gospodarce światowej. W tym kontekście warto wskazać zwłaszcza na postępujący $\mathrm{w}$ bezprecedensowym tempie proces cyfryzacji w sferze ekonomicznej wraz z towarzyszącymi mu atrybutami (m.in. systematyczny wzrost znaczenia handlu elektronicznego, intensywny przepływ danych biznesowych, robotyzacja i wzrost znaczenia sztucznej inteligencji w działalności operacyjnej firm, nowe modele biznesu i interakcji z konsumentami budowane na podstawie cyfryzacji). Paralelnie wzrosła również wyraźnie rola globalnych łańcuchów wartości i związana z tym defragmentaryzacja produkcji. Ponadto, co jest problematyczne w percepcji WTO, nadal przebiega proces regionalnej integracji ekonomicznej (objawiający się w formie zawieranych różnego rodzaju regionalnych porozumieniach handlowych), następuje też intensywny wzrost porozumień bilateralnych oraz porozumień sektorowych, a także widoczne staje się stopniowe przenoszenie dyskusji dotyczącej handlu międzynarodowego na inne fora (poza WTO). W rezultacie wskazane (zaledwie przykładowe) przejawy transformacji globalnej przestrzeni ekonomicznej można jednocześnie intepretować jako kolejne poważne wyzwania stojące aktualnie przed 
WTO. Przedmiotowa instytucja nie określiła jednak jak dotąd swojej roli w nowych uwarunkowaniach politycznych, ekonomicznych i społecznych w przestrzeni międzynarodowej. Wydaje się zatem, iż brak spójnej wizji krajów członkowskich WTO odnośnie do dalszego działania tej organizacji przyczynić się może tylko do dalszego pogłębienia kryzysu w obliczu tak poważnych wyzwań.

\section{Możliwe scenariusze dalszych prac na forum WTO}

Kryzys WTO, w tym ostatnia porażka XI KM, skłaniają do refleksji dotyczącej modelu i zakresu dalszych prac na forum tej organizacji, a także samego kształtu oraz przyszłej roli WTO w gospodarce światowej. Niewątpliwe załamanie filaru negocjacyjnego implikuje próby poszukiwania alternatywnych rozwiązań umożliwiających konstruktywne kontynuowanie rozmów w obszarze tworzenia nowych regulacji handlowych. Jest to szczególnie istotne w sytuacji, kiedy kraje afrykańskie oraz Indie ze względów politycznych i strategicznych blokują nadal wszystkie prace nie związane bezpośrednio z agendą rozwojową Rundy Doha. Jednocześnie państwa te sprzeciwiają się także wspominanym wcześniej nowym inicjatywom, wskazując, iż nie mają one odpowiedniej legitymacji ani mandatu do negocjacji oraz ich zdaniem mogą powodować niepotrzebne rozproszenie aktywności w obszarach innych aniżeli kwestie rozwojowe. Sytuację pogarsza równolegle obserwowany brak konstruktywnej aktywności Stanów Zjednoczonych, które eksponują szczególnie intensywnie w ostatnich miesiącach rozczarowanie sytuacją w WTO, domagając się przy tym głębokich reform instytucjonalnych, obejmujących także funkcjonowanie organu odwoławczego w systemie rozstrzygania sporów. Jednocześnie Stany Zjednoczone w ostatnich tygodniach (marzec 2018) podejmowały bardzo kontrowersyjne decyzje dotyczące implementacji narzędzi taryfowych w prowadzonej polityce handlowej (casus ceł na import stali i aluminium), wzbudzając przez to falę intensywnej krytyki na forum WTO, co destrukcyjnie wpłynęło też na klimat prowadzonych obecnie tutaj prac.

W tej sytuacji kraje, które są zainteresowane kontynuacją rozmów i prac w filarze negocjacyjnym, podejmują aktywność w ramach inicjatyw plurilateralnych (aktualnie w obszarze handlu elektronicznego, ułatwień dla inwestycji, wsparcia MMSP). W chwili obecnej nie ma jednak pewności odnośnie do tego, czy podjęte próby wykorzystania modeli plurilateralnych w dalszych pracach okażą się efektywne. Zasadnicze wątpliwości związane są w tym przypadku z brakiem odpowiedniego zaplecza instytucjonalnego dla obsługi nowych inicjatyw w WTO (np. brak ukonstytuowania formalnych grup roboczych w ramach WTO dla inicjatywy związanej z ułatwieniami inwestycyjnymi oraz wsparcia MMSP), deficytem wizji odnośnie do precyzyjnego kierunku, w którym prace te powinny zmierzać, oraz brakiem wizji oczekiwanych rezultatów tych negocjacji. Dodatkowo mogą się także ujawnić na dalszych etapach prac potencjalne problemy z zakresem i implementacją przygotowanych porozumień. Na razie zatem trudno ocenić, czy rozmowy 
te staną się podstawą przyszłego kompromisu multilateralnego, czy też może pozostaną tylko inicjatywami plurilateralnymi, wiążącymi jedynie kraje partycypujące w danej inicjatywie. Należy zauważyć, iż szczególnie istotną kwestią jest również brak pewności odnośnie do możliwości objęcia (bądź nie) nowych inicjatyw Klauzulą największego uprzywilejowania (Most Favoured Nation Clause, MFN).

Wydaje się, że pogłębiony proces refleksji w filarze negocjacyjnym WTO będzie trwał przynajmniej do połowy 2018 roku. Jest to okres, w którym zainteresowane kraje członkowskie WTO rozpoczynają identyfikację zakresu możliwych tematów/ zobowiązań, badanie dostępnych formatów prowadzenia dyskusji oraz sposoby ich zinstytucjonalizowania. Konieczna jest jednak zmiana podejścia (a więc wyraźna wola polityczna) m.in. Stanów Zjednoczonych, Chin, Indii czy RPA wobec prac na forum WTO, co skutkowałoby wzrostem znaczenia i wartości nowych inicjatyw (choć prawdopodobnie byłoby to jedynie możliwe w przypadku intensyfikacji dyskusji dotyczącej rolnictwa, o co zabiegają Indie). W związku z tym, bazując na aktualnym stanie rozmów w ramach WTO w Genewie oraz w oparciu o ostatnie dyskusje w Davos w styczniu 2018 roku i rozmowy prowadzone na ministerialnej minikonferencji WTO w New Delhi w marcu 2018 roku, wydaje się, iż najbardziej realistycznym scenariuszem na chwilę obecną jest szersze oraz bardziej intensywne wykorzystanie podejścia plurilateralnego. Taki model prac antycypuje wiele krajów WTO (rozwijających się i rozwiniętych), które są sygnatariuszami poszczególnych inicjatyw plurilateralnych. Mają one także nadzieję na transformację w przyszłości tych porozumień wielostronnych w porozumienia multilateralne, chociaż w przypadku rozmów plurilateralnych (co rodzi istotne ryzyko) zawsze identyfikuje się potrzebę zgromadzenia odpowiednio dużej masy krytycznej w ramach danej inicjatywy.

Należy zaznaczyć, iż wykorzystanie podejścia plurilateralnego w pracach WTO nie jest precedensem. W tym kontekście warto przypomnieć, iż do tej pory funkcjonowały dwa zasadnicze modele plurilateralne w międzynarodowych relacjach handlowych. Model I to te inicjatywy, które pozostają poza dorobkiem WTO do czasu, kiedy wszystkie państwa członkowskie nie zgodzą się na ich zmultilateralizowanie. Nie są one częścią porządku prawnego WTO, gdyż ich podstawą nie jest żadna decyzja przedmiotowej organizacji lub mandat zawarty w porozumieniach WTO. Wynik negocjacji prowadzonych w takim modelu obowiązuje jedynie państwa członkowskie partycypujące w takiej inicjatywie. Przykładem implementacji wskazanego modelu były negocjacje Porozumienia w sprawie handlu usługami (Trade in Services Agreement, TISA). Należy dodać w tym miejscu, iż prowadzenie negocjacji plurilateralnych w przedstawionej formule może być zagrożeniem dla systemu multilaterlanego, gdyż powoduje jego stopniową erozję. Model II to z kolei te inicjatywy, które są bezpośrednio częścią dorobku i porządku prawnego WTO, ponieważ ich podstawą są mandaty negocjacyjne, tj. mandaty zawarte w porozumieniach WTO lub mandaty, które zostały wykreowane na podstawie decyzji ministerialnych podjętych podczas Konferencji Ministerialnych. Do tej grupy zaliczane są m.in. Porozumienia w sprawie zamówień publicznych (Agreement on Govern- 
ment Procurement, GPA) i Porozumienie w sprawie handlu towarami technologii informatycznych (Information Technlogy Agreement, ITA). Są one bardzo użytecznym uzupełnieniem dorobku multilateralnego, a ich celem ostatecznym była zawsze multilateralizacja, która związana jest albo ze zdefiniowaną masą krytyczną, albo z zastosowaniem klauzuli MFN lub też z przystąpieniem wszystkich krajów WTO do danej inicjatywy. Tego rodzaju negocjacje są komplementarne w stosun$\mathrm{ku}$ do systemu multilateralnego i umożliwiają progresywną liberalizację. Zatem są korzystnym uzupełnieniem systemu multilateralnego, gdyż żadnego kraju nie dyskryminują. Jak zauważają Adlung i Mamdouh, podejście plurilateralne, chociaż niepozbawione wad i ograniczeń, może umożliwić „ucieczkę" od zablokowania funkcji negocjacyjnej WTO w wyniku utrzymujących się różnic odnośnie do sposobu i wyników zakończenia DDA [Adlung, Mamdouh 2016]. Lawrence podkreśla, iż porozumienia plurilateralne mogą wręcz wspierać zasadniczą działalność WTO i promować pogłębioną integrację ekonomiczną na poziomie gospodarki światowej. Umożliwiają bowiem zmniejszenie instytucjonalnej presji na WTO ze względu na to, iż oferują swoisty kompromis pomiędzy zróżnicowaniem krajów członkowskich a wolą części z nich do poszerzenia wzajemnych zobowiązań w określonych obszarach problemowych. Co ważne, porozumienia plurilateralne mogą również zredukować negatywne oddziaływanie procesu regionalizacji na multilateralny system handlowy i WTO [Lawrence 2011].

$\mathrm{W}$ odniesieniu do aktualnych inicjatyw plurilateralnych (w obszarach handlu elektronicznego, ułatwień dla inwestycji oraz wsparcia MMSP) na obecnym etapie rozmów (stan na marzec 2018 roku) nie można jednoznacznie określić, do jakiego z tych dwóch modeli będą ostatecznie przynależały. Wysoki stopień niepewności sprawia, iż inicjatywy te mogą ewoluować zarówno w kierunku modelu I (potencjalnie groźnego dla systemu multilateralnego), jak i w kierunku modelu II (zdecydowanie bardziej korzystnego dla systemu multilateralnego). Należy jednak zauważyć, iż niezależnie od kierunku tej ewolucji podjęcie prac w tych obszarach zostało zainicjowane przez zainteresowane kraje członkowskie, które sygnowały wspólne stanowiska w ww. sektorach podczas 11 KM WTO. Wprawdzie wspólne stanowiska określonej grupy państw w danym obszarze problemowym nie są tożsame z mandatem wszystkich krajów członkowskich WTO, to jednak już osiągnięty konsensus w mniejszym gronie pozwoli przynajmniej na rozpoczęcie rozmów, co też jest wartościowe w sytuacji zablokowania funkcji negocjacyjnej tej instytucji. Warto jeszcze dodać, iż jak dotąd odbyły się w WTO w lutym i marcu 2018 roku pojedyncze spotkania w obszarze handlu elektronicznego, ułatwień dla inwestycji oraz wsparcia MSMEs. Były to jednak posiedzenia o charakterze organizacyjnym, poświęcone na dyskusję dotyczącą przygotowania ram dla przyszłego procesu rozmów. W chwili obecnej odbywa się także odrębna debata na temat tego, czy wskazane inicjatywy (odnośnie do których nie podjęto decyzji podczas $11 \mathrm{KM}$, a jedynie podpisano wspólne stanowiska: ułatwienia dla inwestycji, handel elektroniczny oraz wsparcie MMSP) mają mandat (czy też nie) w dotychczasowym dorobku WTO. Opinie tutaj 
są podzielone, zwolennicy wskazują, że taką bazą może być np. art. XVIII GATS dotyczący podejmowania dodatkowych zobowiązań, ale oponenci z taką interpretacją się nie zgadzają.

\section{Zakończenie}

Pomimo zasygnalizowanych poważnych problemów oraz wyzwań stojących przed WTO wydaje się jednak, iż instytucja ta może nadal odgrywać istotną rolę w gospodarce światowej. Biorąc bowiem nawet pod uwagę wszystkie ułomności WTO, a także obiektywne różnice pomiędzy krajami członkowskimi utrudniające postęp w negocjacjach multilateralnych, należy stwierdzić, że wszelako spójny, transparentny i przewidywalny zestaw regulacji zarządzających handlem międzynarodowym może być źródłem długoterminowych korzyści dla wszystkich podmiotów gospodarki światowej, nawet w tak niesprzyjającej sytuacji globalnej jak obecnie (nie tylko dla aktorów państwowych, ale także dla przedsiębiorstw i organizacji pozarządowych). Ponadto funkcjonowanie platformy (jaką jest i może być dalej WTO) zarówno dyskusji, koordynacji, jak i wypracowywania konkretnych regulacji w handlu międzynarodowym sprzyja osiąganiu wymiernych pozytywnych efektów rozwojowych oraz katalizuje wzrost gospodarczy w krajach członkowskich z wykorzystaniem wymiany międzynarodowej ${ }^{3}$. Blanchard twierdzi nawet, iż właśnie efekty globalizacji, tj. m.in. defragmentaryzaja produkcji i wzrost znaczenia globalnych łańcuchów wartości, dostarczają kolejnych argumentów wzmacniających znaczenie multilateralnego podejścia do handlu światowego i zachowania relewantności WTO [Blanchard 2013]. Pomimo problemów w filarze negocjacyjnym WTO nie można również zapominać (i przekreślać) wartości tej organizacji w innych istotnych dla handlu międzynarodowego obszarach. Już wypracowane regulacje i procedury w konkretnych obszarach nadal zachowują swoją wartość utylitarną. Co więcej, Grappo i Piermartini sugerują, opierając się na przeprowadzonym modelowaniu i badaniach empirycznych, iż generalnie aktywność WTO redukuje wyraźnie niepewność związaną z polityką handlową realizowaną przez kraje członkowskie organizacji [Grappo, Piermartini 2014]. Należy jednak zauważyć, iż WTO jest instytucją kreowaną przez państwa członkowskie (tzw. member driven organization). Zatem to od zachowania krajów członkowskich (i woli politycznej ich reprezentantów) zależy w istocie rzeczy zakres podejmowanych prac na forum tej instytucji oraz późniejsze rezultaty. Jak zauważał Wilkinson, trudne interakcje i spory pomiędzy krajami członkowskimi WTO podczas procesu negocjacyjnego są nieuniknione i stanowią część współczesnej areny polityki handlowej [Wilkinson 2006]. W tych warunkach trudno jednak oczekiwać, iż na poziomie działań operacyjnych instytucja ta będzie w stanie spełniać wszystkie (często sprzeczne) oczekiwania związane z zarządzaniem w sferze handlu na poziomie globalnym.

3 Znamienne, iż taką funkcję WTO silnie eksponuje w ostatnim swoim corocznym raporcie poświęconym najnowszym trendom w handlu międzynarodowym [WTO 2017j]. 
Konieczne jest więc realistyczne podejście do oceny działań WTO i jej możliwości wpływu na kształtowanie globalnej przestrzeni handlowej. Obiektywne zmiany w gospodarce światowej sprawiają, iż WTO powinna również dostosować swoją agendę prac do nowych trendów ekonomicznych oraz społecznych, chcąc zachować wiarygodność i legitymizację. Nie sposób ignorować przebiegającej transformacji cyfrowej, która rodzi wiele długoterminowych skutków nie tylko dla wymiany handlowej, ale także dla funkcjonowania sfer politycznej, biznesowej i społecznej we wszystkich krajach członkowskich WTO.

Jednocześnie wobec aktualnego kryzysu w filarze negocjacji multilateralnych wydaje się, iż realnie warte wsparcia jest podejście plurilateralne przynajmniej do części tematów negocjacyjnych (w obszarach handlu elektronicznego, ułatwień dla inwestycji oraz wsparcia MMSP). Podejście to, jakkolwiek jest ułomnym rozwiązaniem substytucyjnym wobec negocjacji multilateralnych, to jednak w obecnej sytuacji może być skuteczną próbą przynajmniej wznowienia rozmów, a w przyszłości także bazą do rozmów multilateralnych w konkretnych obszarach. Warto dodać, iż tego rodzaju podejście plurilateralne było już wcześniej wykorzystywane z sukcesem w WTO. Ważne jest jednak także, aby urzeczywistnienie inicjatyw plurilateralnych stało się bezpośrednią częścią dorobku i porządku prawnego WTO.

\section{Literatura}

Adlung R., Mamdouh H., 2016, Plurilateral trade agreements: an escape route for the WTO?, WTO Working Paper Economic Research and Statistics Division ERSD-2017-03, Geneva.

Baldwin R., Evenett S. (red.), 2009, The Collapse of Global Trade, Murky Protectionism and the Crisis: recommendations for the G20, Centre for Economic Policy Research, London.

Baldwin R., 2016, The World Trade Organization and the Future of Multilateralism, Journal of Economic Perspectives, vol. 30, no.1, Winter 2016, s. 95-116.

Blanchard E.J., 2014, What global fragmentation means for the WTO: article XXIV, behind-the-border concessions, and a new case for WTO limits on investment incentives, WTO Working Paper Economic Research and Statistics Division ERSD-2014-03, Geneva.

Drabek Z., 2010, Is the WTO Attractive Enough for Emerging Economies? Critical Essays on the Multilateral Trading System, Palgrave McMillan, UK.

Elsig M., 2016, The Functioning of the WTO: Options for Reform and Enhanced Performance, E15 Expert Group on the Functioning of the WTO - Policy Options Paper, E15Initiative. International Centre for Trade and Sustainable Development (ICTSD) and World Economic Forum, Geneva.

European Commission, 2016, Report from the Commission to the European Parliament and the Council on trade and investment barriers, Brussels.

Groppo V., Piermartini R., 2014, Trade policy uncertainty and the WTO, WTO Working Paper Economic Research and Statistics Division ERSD-2014-23, Geneva.

Lawrence R.Z., 2011, Competing with regionalism by revitalizing the WTO, Trade and Development Symposium, International Centre for Trade and Sustainable Development Center.

Nowicki M., 2014, Global governance w obszarze handlu międzynarodowego - rola WTO, Prace Naukowe Uniwersytetu Ekonomicznego we Wrocławiu, nr 369. 
Petersman E. (red.), 2005, Reforming the World Trading System, Legitimacy, Efficiency and Democratic Governance, Oxford University Press, New York.

Van Grasstek C., 2013, The History and Future of the WTO, WTO Geneva.

Wilkinson R., 2006, The WTO. Crisis and the Governance of Global Trade, Routledge, London and New York.

WTO, 1995, Agreement Establishing the World Trade Organisation (WTO), www.wto.org.

WTO, 1995a, Agreement on Subsidies and Countervailing Measures, www.wto.org.

WTO, 1995b, Trade Related Aspects of Intellectual Property Rights, www.wto.org.

WTO, 2006, WTO News: Speeches - DG Pascal Lamy (6 July 2006), https://www.wto.org/english/ news_e/sppl_e/sppl31_e.htm.

WTO, 2017, World Trade Statistical Review, WTO Geneva.

WTO, 2017a, Ministerial decision on fisheries subsidies, WT/MIN(17)/64.

WTO, 2017b, Work programme on electronic commerce, WT/MIN(17)/65.

WTO, 2017c, TRIPS non-violation and situation complaints, WT/MIN(17)/66.

WTO, 2017d, Work programme on small economies, WT/MIN(17)/63.

WTO 2017e, Joint ministerial statement on services domestic regulation, WT/MIN(17)/61.

WTO 2017f, Joint statement on electronic commerce, WT/MIN(17)/60.

WTO $2017 \mathrm{~g}$, Joint ministerial statement on investment facilitation for development, WT/MIN(17)/59.

WTO 2017h, Joint ministerial statement - declaration on the establishment of a WTO informal work programme for MSMES, WT/MIN(17)/58

WTO, 2017i, Address by Mr Roberto Azevêdo WTO Director-General, MC11 Closing Session 13.12.2017, WT/MIN(17)/74.

WTO, 2017j, World Trade Report, Trade, Technology and Jobs, WTO, Geneva. 